\title{
Nitrogen use efficiency and fertiliser fate in a long-term experiment with winter cover crops
}

\author{
J.L. Gabriel, M. Alonso-Ayuso, I. García-González, C. Hontoria, M. Quemada* \\ Technical University of Madrid, Dpto. Producción Agraria, Avd. Complutense s/n, 28040 Madrid, Spain
}

\section{A R T I C LE I N F O}

\section{Article history:}

Received 11 December 2015

Received in revised form 26 April 2016

Accepted 28 April 2016

\section{Keywords:}

Labelled ${ }^{15} \mathrm{~N}$ fertiliser

Vetch

Barley

Fallow

Maize

Fertiliser recovery

Mediterranean climate

\begin{abstract}
A B S T R A C T
The use of winter cover crops enhances environmental benefits and, if properly managed, may supply economic and agronomic advantages. Nitrogen retained in the cover crop biomass left over the soil reduces soil $\mathrm{N}$ availability, which might enhance the $\mathrm{N}$ fertiliser use efficiency of the subsequent cash crop and the risk of depressive yield and pre-emptive competition. The main goal of this study was to determine the cover crop effect on crop yield, $\mathrm{N}$ use efficiency and fertiliser recovery in a 2-year study included in a long-term (10 years) maize/cover crop production system. Barley (Hordeum vulgare L) and vetch (Vicia sativa L), as cover crops, were compared with a fallow treatment during the maize intercropping period. All treatments were cropped following the same procedure, including $130 \mathrm{~kg} \mathrm{Nha}^{-1}$ with ${ }^{15} \mathrm{~N}$ fertiliser. The $\mathrm{N}$ rate was reduced from the recommended $\mathrm{N}$ rate based on previous results, to enhance the cover crop effect. Crop yield and $\mathrm{N}$ uptake, soil $\mathrm{N}$ mineral and ${ }^{15} \mathrm{~N}$ fertiliser recovered in plants and the soil were determined at different times. The cover crops behaved differently: the barley covered the ground faster, while the vetch attained a larger coverage and $\mathrm{N}$ content before being killed. Maize yield and biomass were not affected by the treatments. Maize $\mathrm{N}$ uptake was larger after vetch than after barley, while fallow treatment provided intermediate results. This result can be ascribed to $\mathrm{N}$ mineralization of vetch residues, which results in an increased $\mathrm{N}$ use efficiency of maize. All treatments showed low soil $\mathrm{N}$ availability after the maize harvest; however, barley also reduced the $\mathrm{N}$ in the upper layers before maize planting, increasing the risk of pre-emptive competition. In addition to the year-long effect of residue decomposition, there was a cumulative effect on the soil's capacity to supply $\mathrm{N}$ after 7 years of cover cropping, larger for the vetch than for the barley.
\end{abstract}

2016 Elsevier B.V. All rights reserved.

\section{Introduction}

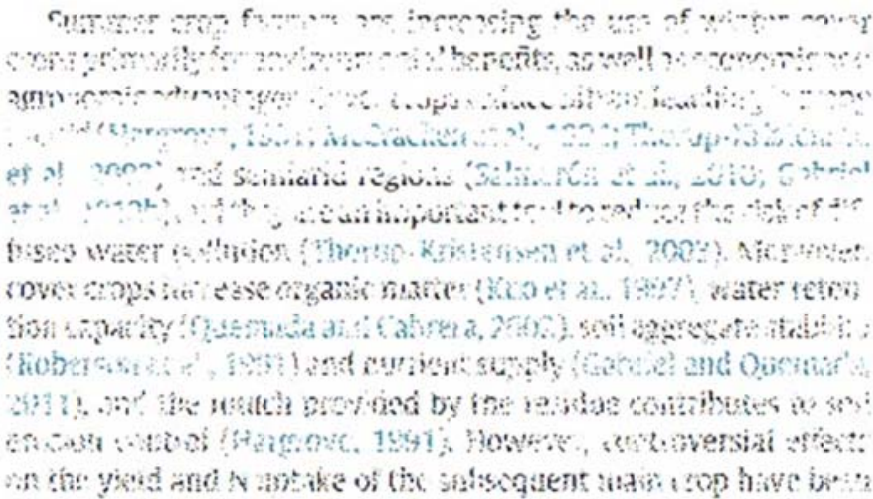

\footnotetext{
* Corresponding author.

E-mail address: miguel.quemada@upm.es (M. Quemada).
}

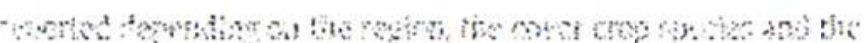

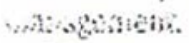

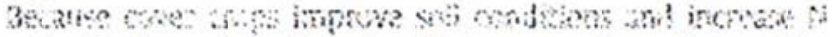

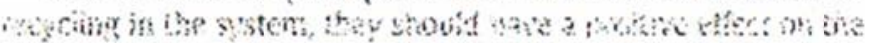

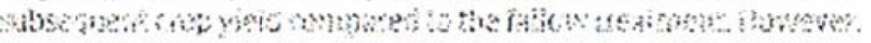

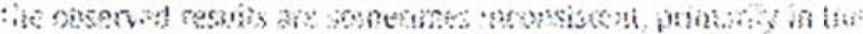

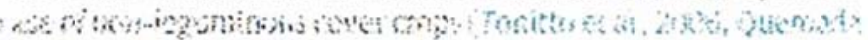

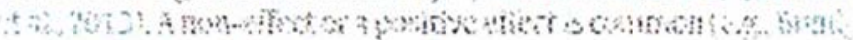

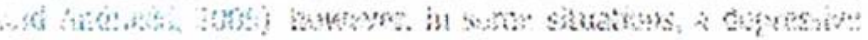

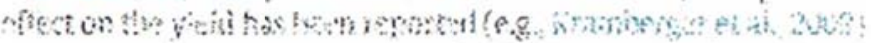

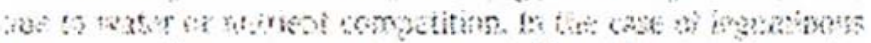

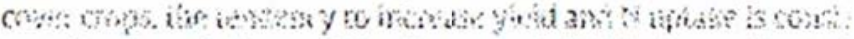

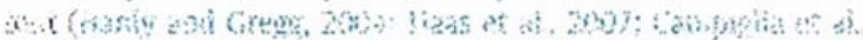

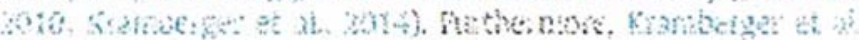

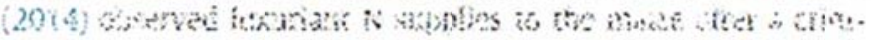

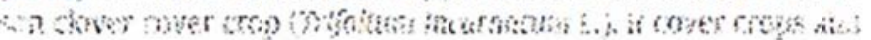

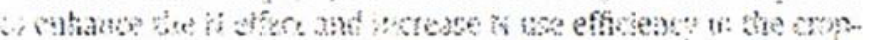

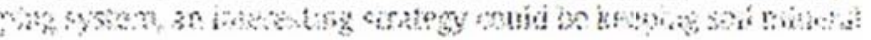




\section{INTRODUCTION}

Summer crop farmers are increasing the use of winter cover crops primarily for environmental benefits, as well as economic and agronomic advantages. Cover crops reduce nitrate leaching in many humid (Hargrove, 1991; McCracken et al., 1994; Thorup-Kristensen et al., 2003) and semiarid regions (Salmerón et al., 2010; Gabriel et al. 2012b) and they are an important tool to reduce the risk of diffused water pollution (Thorup-Kristensen et al., 2003). Moreover, cover crops increase organic matter (Kuo et al., 1997), water retention capacity (Quemada and Cabrera, 2002), soil aggregate stability (Roberson et al., 1991) and nutrient supply (Gabriel and Quemada, 2011), and the mulch provided by the residue contributes to soil erosion control (Hargrove, 1991). However, controversial effects on the yield and $\mathrm{N}$ uptake of the subsequent main crop have been reported depending on the region, the cover crop species and the management.

Because cover crops improve soil conditions and increase $\mathrm{N}$ recycling in the system, they should have a positive effect on the subsequent crop yield compared to the fallow treatment. However, the observed results are sometimes inconsistent, primarily in the case of non-leguminous cover crops (Tonitto et al., 2006; Quemada et al., 2013). A noneffect or a positive effect is common (e.g., Bundy and Andraski, 2005), however, in some situations, a depressive effect on the yield has been reported (e.g., Kramberger et al., 2009) due to water or nutrient competition. In the case of leguminous cover crops, the tendency to increase yield and $\mathrm{N}$ uptake is consistent (Hanly and Gregg, 2004; Haas et al., 2007; Campiglia et al., 2010; Kramberger et al., 2014). Furthermore, Kramberger et al. (2014) observed luxuriant $\mathrm{N}$ supplies to the maize after a crimson clover cover crop (Trifolium incarnatum L.). If cover crops aim to enhance the $\mathrm{N}$ effect and increase $\mathrm{N}$ use efficiency in the cropping system, an interesting strategy could be keeping soil mineral $\mathrm{N}$ at a level in which losses are minimized and crop availability is ensured.

Enriched ${ }^{15} \mathrm{~N}$ fertilisation is a valuable method to differentiate between $\mathrm{N}$ uptake from the fertiliser and from other sources. Fertilisation rates close to the crop's N demand can result in fertiliser use efficiencies of approximately 50\%, as observed by Reddy and Reddy (1993) in the Piedmont region (NC, USA), by Bundy and Andraski (2005) in Illinois, by Normand et al. (1997) in France and by Gabriel and Quemada (2011) in Spain. In the last study, it was reported that neither a legume nor a grass cover crop had 
an effect on the $\mathrm{N}$ use efficiency (NUE) with respect to fallow treatment. Even if more $\mathrm{N}$ was taken up by the main crop after a vetch cover crop than after a fallow period, the NUE did not increase, meaning that the extra $\mathrm{N}$ uptake by the main crop came from sources other than the fertiliser. In this case, there could be an effect of cover crops on the NUE when the fertiliser application is below the crop's $\mathrm{N}$ requirements. This is relevant because it may allow the cover crop N-effect and the NUE in the cropping system to be optimized. Bundy and Andraski (2005) observed that there was an effect of winter rye cover crop (Secale cereale L.) on maize grain, biomass and $\mathrm{N}$ uptake when the fertiliser rate was reduced, which could potentially be masked at non-limiting $\mathrm{N}$ fertiliser rates. Moreover, the initial soil mineral $\mathrm{N}\left(\mathrm{N}_{\min }\right)$ could be a relevant factor affecting maize NUE; however, this needs to be clarified, particularly at reduced fertiliser rates.

Cover crops can also lead to differences in the soil $\mathrm{N}$ availability at sowing time, as well as in the main cropping season (Gabriel et al., 2014). Leguminous cover crops do not reduce soil available $\mathrm{N}$ at sowing with respect to a fallow treatment (Gabriel and Quemada, 2011); however, non-leguminous cover crops are prone to reducing it (Wagger and Megel, 1988; Thorup-Kristensen, 2001). This could lead to N pre-emptive competition with the main crop, which is often related to microbial immobilization, as reported by Garibay et al. (1997) or Kramberger et al. (2014) for grasses as cover crops. However, this initial competition and lower growth rate can be switched to an enhancement of growth in the later stages due to residue mineralization and $\mathrm{N}$ supply (Verhulst et al., 2011; Kramberger et al., 2014). The $\mathrm{N}$ immobilization can be minimised by using cover crops with low $\mathrm{C} / \mathrm{N}$ ratio, mixing species or adjusting the cover crop killing date (Rüegg et al., 1998; Doane et al., 2009; Alonso-Ayuso et al., 2014). Reducing $\mathrm{N}$ fertilisation should highlight the effects between different cover cropping strategies.

Cover crops are usually grown under non-optimal meteorological conditions; therefore biomass and cover crop establishment can be deficient (Lal et al., 1991; Gabriel et al., 2013). Under semiarid conditions, grasses are usually better adapted because of their tolerance to drought conditions (Bilbro, 1991; Unger and Vigil, 1998; Ramirez-Garcia et al., 2015). However, there are few a studies combining semiarid drought conditions with low $\mathrm{N}_{\min }$ availability, where legumes could be better adapted. More information is 
needed concerning the performance of different cover crops as $\mathrm{N}$ catch crops under low $\mathrm{N}_{\min }$ availability.

The main goal of this study was to examine the effect of replacing fallow periods with cover crops in a long-term maize production system with a limited $\mathrm{N}$ fertilisation supply. The specific objectives were to determine (i) if cover crops could increase the crop yield, $\mathrm{N}$ uptake and NUE of ${ }^{15} \mathrm{~N}$ fertiliser applied to maize and (ii) if cover crops were adapted to low $\mathrm{N}$ availability conditions.

\section{MATERIAL AND METHODS}

\subsection{Soil and site}

The study was conducted during 2 years (from October 8, 2012 to September 25, 2014) at La Chimenea field Station $\left(40^{\circ} 03^{\prime} \mathrm{N}, 03^{\circ} 31^{\prime} \mathrm{W}\right.$, altitude $\left.550 \mathrm{~m}\right)$ located in the central Tajo River Basin near Aranjuez (Madrid, Spain). The soil at the field site is mapped as silty clay loam (Typic Calcixerept; Soil Survey Staff, 2014), being deep with a fairly uniform texture for $1.2 \mathrm{~m}$, rich in organic matter and alkaline. The climate of the area is Mediterranean semiarid (Papadakis, 1966) with a $14.2^{\circ} \mathrm{C}$ mean annual temperature and approximately $350 \mathrm{~mm}$ average rainfall with high interannual variability. Additional information concerning the soil and climatic conditions can be found in Gabriel and Quemada (2011). Measurements during the experiment of the air and soil temperature, humidity, radiation, PAR (photosynthetically active radiation) and wind were recorded by a CR23X micrologger in a Campbell Scientific station located $<100 \mathrm{~m}$ from the experiment (Fig.1).

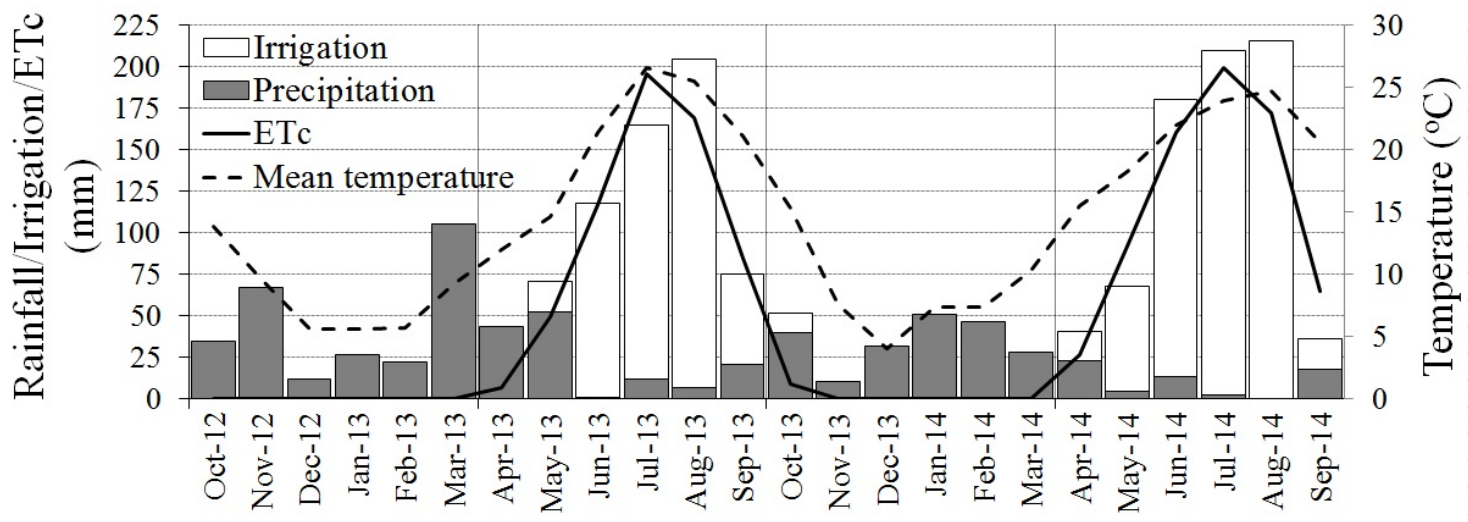

Figure 1. Monthly mean temperature, rainfall, irrigation and maize evapotranspiration observed during the 2 year experimental period in Aranjuez (Madrid, Spain). 


\subsection{Experimental design and crop management}

The study was conducted as a long-term experiment based on two winter cover crop treatments sowed every year since October 2006 and compared to fields with a fallow treatment. The two cover crop treatments were barley (Hordeum vulgare L., cv. Vanessa, $180 \mathrm{~kg} \mathrm{ha}^{-1}$ ) and vetch (Vicia sativa L., cv. Aitana, $150 \mathrm{~kg} \mathrm{ha}^{-1}$ ), and the design corresponded to four replications completely randomly distributed in 12 plots (12 m x $12 \mathrm{~m}$ ). After killing the cover crops in 2013 and 2014, maize (Zea mays L.) was planted in all plots and one microplot $(2 \mathrm{~m} \mathrm{x} 2 \mathrm{~m}$ ) was established within each plot to monitor the ${ }^{15} \mathrm{~N}$-labelled fertiliser uptake, recovery and fate. Different microplot positions were used each year with a minimum separation of $4 \mathrm{~m}$. The preceding summer cash crops were maize between 2007 and 2010 and a fallow period in 2011, followed by a sunflower crop (Helianthus annuus L., var. Sambro) in 2012 to break the maize monoculture. Mineral $\mathrm{N}$ fertilisation during these years consisted of $210 \mathrm{~kg} \mathrm{ha}^{-1}$ per year during the maize crops and nothing during the fallow and sunflower seasons to increase $\mathrm{N}$ use efficiency in the cropping system. More than $90 \%$ of the cash crop residues were removed from the plots each year.

The cover crops were broadcast by hand with a shallow cultivator (depth $\sim 0.05 \mathrm{~m}$ ) followed by a seedbed finisher, which was passed over all of plots in early October (October 8, 2012 and October 10, 2013) for sowing. All treatments were treated with one application of $2 \%$ glyphosate (N-phosphonomethyl glycine, $0.7 \mathrm{~kg}$ a.e. ha ${ }^{-1}$ ) in late winter (March 15, 2013 and March 14, 2014), and the straw was chopped when dry the day before sowing the maize. Four $0.5 \mathrm{~m}$ x $0.5 \mathrm{~m}$ squares were randomly harvested from each $12 \mathrm{~m} \times 12 \mathrm{~m}$ plot, without interfering with the microplots before killing the cover crops. The aerial biomass was cut by hand at soil level, dried, weighed and ground. From these samples, the cover crop's aboveground biomass and $\mathrm{N}$ contribution to the subsequent maize were determined. The ground cover was digitally analysed every 2 weeks, from emergence to killing date, with five nadir images per plot following the Ramirez-García et al. (2015) methodology.

In April 18, 2013 and April 7, 2014, maize (P1574G-98 Pioneer, FAO class 700) was directly sowed over the cover crop residues in rows separated by $0.74 \mathrm{~m}$ and spaced every $0.18 \mathrm{~m}$ within the rows, resulting in a plant population density of 75,000 plants $\mathrm{ha}^{-1}$. The maize was harvested on October 07, 2013 and September, 2014, and all of the 
maize residues were removed from the plots. Water was uniformly applied using a sprinkle irrigation system $\left(12 \times 12 \mathrm{~m}^{2}, 9.5 \mathrm{~mm} \mathrm{~h}^{-1}\right)$ according to crop evapotranspiration (ETc) requirements calculated using the FAO method (Allen et al., 1998), and a 10\% surplus was added as a leaching fraction to avoid soil salinization (Gabriel et al., 2012a). For this, the reference evapotranspiration (ETo) was calculated using the Penman-Monteith model and corrected by the crop coefficient obtained following the relationship proposed for maize in semiarid climatic conditions (Martinez-Cob, 2008). To increase the cover crop's effect on $\mathrm{N}$ recovery, the fertiliser supplied was lower than the $170 \mathrm{~kg} \mathrm{~N} \mathrm{ha}^{-1}$ recommended for the region (Quemada et al., 2014). Each microplot received $130 \mathrm{~kg} \mathrm{~N}^{-1}$ as enriched ammonium nitrate $\left(5 \%{ }^{15} \mathrm{~N}\right.$ double labelled; Cambridge Isotope Laboratories, Andover, MA, USA), which was applied when the maize had 4-6 leaves (May 23, 2013 and May 26, 2014). In this study, the established microplots established were larger than in 2007/2009 (Gabriel and Quemada, 2011) and the ${ }^{15} \mathrm{~N}$ richness of the labelled fertiliser was doubled to ensure the solidity of the results. The ${ }^{15} \mathrm{~N}$ fertiliser was applied to the soil surface of the microplot in $4 \mathrm{~L}$ of distilled water using a hand sprayer. The rest of the experimental area received the same $\mathrm{N}$ application by hand broadcasting of the non-labelled fertiliser followed by an irrigation event to enhance infiltration and avoid ammonia volatilization losses. Each year, before sowing the maize, $30 \mathrm{~kg} \mathrm{P} \mathrm{ha}^{-1}$ and $100 \mathrm{~kg} \mathrm{~K} \mathrm{ha}^{-1}$ of fertiliser were applied.

\subsection{Crop analysis}

At maize maturity, a central area of $0.75 \mathrm{~m} \times 1.5 \mathrm{~m}$ was harvested from each microplot, separated into plant components (grain and the rest of the aerial biomass), dried in a $65^{\circ} \mathrm{C}$ oven, weighed and ground. Following the methodology described by Gabriel and Quemada (2011), a subsample was taken to determine the total $\mathrm{N}$ and ${ }^{15} \mathrm{~N}$ concentration, and the same $\mathrm{N}$ and ${ }^{15} \mathrm{~N}$ determination was done for plants outside the microplot for comparison. For each microplot, plant $\mathrm{N}$ content $\left(\mathrm{N}_{\mathrm{t}}\right)$ and labelled-fertiliser recovery $\left(\mathrm{N}_{\mathrm{R} \text {-plant }}\right)$ were calculated for each plant component, and summed to obtain values for the entire aerial part of the plant. Labelled-fertiliser recovery was calculated from the ratio $\mathrm{N}_{\mathrm{t}} \cdot(c-b) /(a-b)$, where $a$ is the atomic $\%{ }^{15} \mathrm{~N}$ in the fertiliser, $b$ the atomic $\%{ }^{15} \mathrm{~N}$ in the control plant component without labelled fertiliser (measured in other plants in the same plot outside the microplot), and $c$ is the atomic $\%{ }^{15} \mathrm{~N}$ in the plant component with ${ }^{15} \mathrm{~N}$ fertilisation (Hauck and Bremner, 1976). Nitrogen use efficiency (i.e., ${ }^{15} \mathrm{~N}$ recovery from the fertiliser) was calculated as the percentage of total $\mathrm{N}$ fertiliser applied $\left(\mathrm{N}_{\text {Fert }}\right)$ 
recovered in the maize $\left(\mathrm{NUE}=100 \cdot \mathrm{N}_{\mathrm{R} \text {-plant }} / \mathrm{N}_{\text {Fert }}\right)$. The difference between $\mathrm{N}_{t}$ and $\mathrm{N}_{\mathrm{R}-}$ plant represents the amount of $\mathrm{N}$ content in the maize crop from sources other than the fertiliser (NOS), as the $\mathrm{N}$ initially available or the $\mathrm{N}$ mineralized from the soil and from the previous cover crop residue.

\subsection{Soil analysis}

Soil samples were collected from all of the microplots at the maize harvest. For each microplot, five soil samples were obtained for each depth by mixing two soil cores taken with an Eijkelkamp ${ }^{\circledR}$ helicoidal auger to a depth of $1 \mathrm{~m}$ at $0.2 \mathrm{~m}$ intervals. Control soil samples without labelled fertiliser (measured in other holes in the same plot outside the microplot) were also collected. Soil samples were placed in a plastic box, transported and air-dried. Subsamples were taken for determination of total $\mathrm{N}$ and ${ }^{15} \mathrm{~N}$ concentration. For each microplot, soil $\mathrm{N}$ content and $\mathrm{N}$ labelled-fertiliser recovered $\left(\mathrm{N}_{\mathrm{R} \text {-soil }}\right)$ were calculated for each layer. $\mathrm{N}_{\mathrm{R} \text {-soil }}$ was calculated following the same equation used for maize $\mathrm{N}_{\mathrm{R}-\text { plant }}$.

Four soil cores were taken from each plot to $1 \mathrm{~m}$ depth with $0.2 \mathrm{~m}$ intervals at maize sowing and harvest. These were combined by depth to provide a composite profile of the five samples. The soil samples were placed in a plastic box and firmly closed, immediately transported and refrigerated $\left(4^{\circ} \mathrm{C}\right.$ to $\left.6^{\circ} \mathrm{C}\right)$. Within the three days, the samples were extracted with $1 \mathrm{M} \mathrm{KCl} \mathrm{(30} \mathrm{g} \mathrm{of} \mathrm{soil:} 150 \mathrm{~mL}$ of $\mathrm{KCl})$, centrifuged, and decanted, and a subsample of the supernatant volume was stored in a freezer until later analysis. The nitrate concentration in the extracts was determined via spectrophotometry after a reduction with a cadmium column (Keeney and Nelson, 1982), and ammonium was measured using the method of Solorzano (1969).

Plant and soil samples were analysed for total $\mathrm{N}$ using the Dumas combustion method (LECO FP-428 analyzer, LECO Corporation, St. Joseph, MI, USA), and for ${ }^{15} \mathrm{~N}$ concentration using an Isotope Ratio Mass Spectrometer (Delta ${ }^{\text {Plus }}$ XL, Thermo Fisher Scientific, Waltham, MA, USA). A simple $\mathrm{N}$ balance was conducted to evaluate the differences in soil contribution during the maize cropping period. The apparent $\mathrm{N}$ mineralization (ANM) was calculated by adding the $\mathrm{N}$ uptake by the plant to the soil mineral content in the upper metre of the soil profile $\left(\mathrm{N}_{\min }\right)$ after harvest and subtracting the initial $\mathrm{N}_{\min }$ before sowing and the $\mathrm{N}$ fertiliser applied. The apparent $\mathrm{N}$ mineralization assumes that the $\mathrm{N}$ gaseous emissions equal the $\mathrm{N}$ atmospheric 
depositions and that $\mathrm{N}$ leaching is negligible. The ANM was calculated to quantify the $\mathrm{N}$ supplied by the mineralization of the soil plus the cover crop residues.

\subsection{Statistical analyses}

Analyses of variance (ANOVA) were performed for each variable over the entire experiment, considering the treatment and year as fixed factors. Means were separated by Duncan's multiple range test, and the statistical significance was evaluated at $\mathrm{P} \leq$ 0.05. The statistical analyses were made using R commander (Hutcheson, 2013).

\section{RESULTS}

\subsection{Climatic data and irrigation values}

There were some differences in the amount and distribution of rainfall between the years of the study; however, they were representative of an average year (Fig. 1). During the cover crop seasons (October-March), rainfall amounted to $269 \mathrm{~mm}$ and 210 $\mathrm{mm}$, respectively, compared to the $30-\mathrm{yr}$ average of $253 \mathrm{~mm}$ (data not shown). During the first autumn (October December), rainfall was slightly higher than during the second year, $114 \mathrm{~mm}$ with respect to $83 \mathrm{~mm}$, with important differences especially in November $(67 \mathrm{~mm}$ vs. $10 \mathrm{~mm})$. The rain during the spring was also variable. From April to May, it rained $97 \mathrm{~mm}$ and $28 \mathrm{~mm}$, respectively, in the 2 years.

The temperature followed a classic Mediterranean distribution with mild winters and hot summers (Fig. 1). However, plant growth was limited by the low temperatures during at least 3 months (December-February) because of the additional continental influence. The average temperatures in December and January were $5.7^{\circ} \mathrm{C}$ in both years but nearly $2^{\circ} \mathrm{C}$ colder during November and December in 2013 compared to 2012.

High temperature and low rainfall determine the high irrigation demand during the maize growing period (April-September). In 2013 and 2014, annual ETo was $819 \mathrm{~mm}$ and $872 \mathrm{~mm}$, respectively, and the ETc during the maize crop was $633 \mathrm{~mm}$ and 716 mm, respectively (Fig. 1). Irrigation was $552 \mathrm{~mm}$ in 2013 and $589 \mathrm{~mm}$ in 2014. 


\subsection{Cover crops: Ground cover, biomass and N content}

The barley covered the soil faster than the vetch; however these differences tended to disappear during the winter, and the vetch covered the ground better than the barley by the time of cover crop killing (Fig. 2). Differences in aerial biomass were observed between years and treatments (Table 1). In the first year, there was no difference between the barley and vetch in aerial biomass, averaging approximately $3000 \mathrm{~kg}$ d.m. $\mathrm{ha}^{-1}$. In the second year, the vetch produced more biomass than the barley $\left(\sim 550 \mathrm{~kg} \mathrm{ha}^{-}\right.$

${ }^{1}$ ), as interactions between the year and treatment were significant. Low precipitation during the 2013/14 November-December period, coupled with the $2^{\circ} \mathrm{C}$ temperature decrease during the same period, resulted in biomass reduction for both cover crops. A yearly climatic effect was also observed in differences in the ground cover during the autumn (Fig. 2). Biomass produced by the fallow treatment was negligible in both years.

The $\mathrm{N}$ concentrations in the aerial biomass also differed between treatments. The vetch biomass presented a stable $3.7 \%$ during both years; however, the barley increased from $1.2 \%$ in 2013 to $2.0 \%$ in 2014 . Both years, the $\mathrm{N}$ content was significantly larger in the vetch than in the barley.

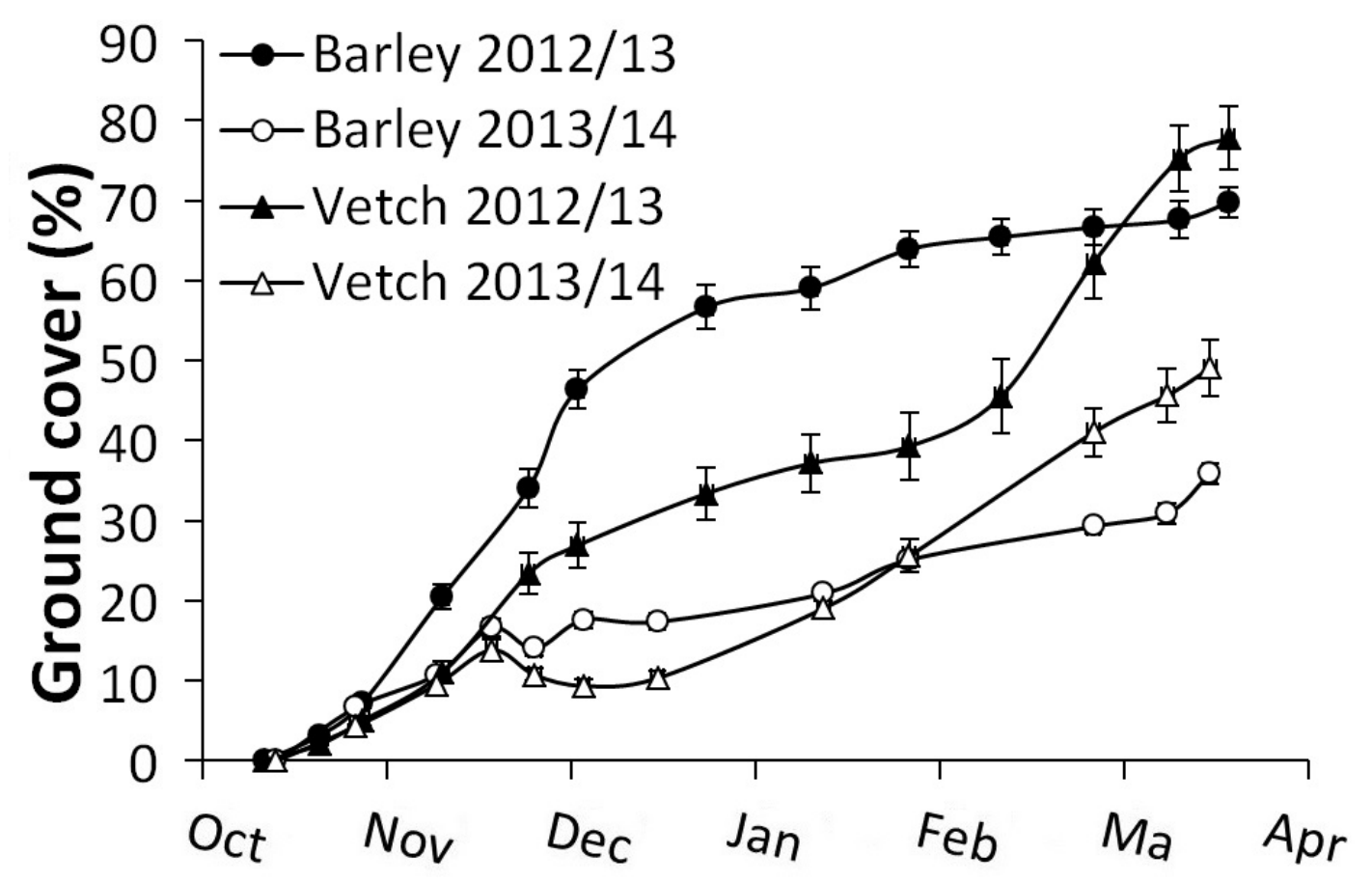

Figure 2. Observed ground cover of two cover crops during both experimental periods. Vertical bars represent the standard error. 
Table 1. Biomass, $\mathrm{N}$ concentration and $\mathrm{N}$ content in the aerial part of cover crops and spontaneous vegetation at the end of the cover crop growing season for three treatments in two consecutive years.

\begin{tabular}{lllll}
\hline $\begin{array}{l}\text { Growing } \\
\text { season }\end{array}$ & Treatment & $\begin{array}{l}\text { Aerial Biomass } \\
\left(\mathrm{kg} \mathrm{d.m.} \mathrm{ha}^{-1}\right)\end{array}$ & $\begin{array}{l}\text { N Concentration } \\
\left(\mathrm{g} \mathrm{N} \mathrm{kg}^{-1} \mathrm{~d} . \mathrm{m} .\right)\end{array}$ & $\begin{array}{l}\mathrm{N} \text { Content } \\
(\mathrm{kg} \mathrm{N} \mathrm{ha} \\
1\end{array}$ \\
\hline $2012 / 13$ & Vetch & $2591.3 \mathrm{a}$ & $37.0 \mathrm{a}$ & $96.5 \mathrm{a}$ \\
& Barley & $3423.2 \mathrm{a}$ & $12.1 \mathrm{~b}$ & $40.4 \mathrm{~b}$ \\
& Fallow & $0.0 \mathrm{~b}$ & - & $0.0 \mathrm{c}$ \\
\hline $2013 / 14$ & Vetch & $1106.7 \mathrm{a}$ & $37.1 \mathrm{a}$ & $41.3 \mathrm{a}$ \\
& Barley & $540.5 \mathrm{~b}$ & $20.3 \mathrm{~b}$ & $11.0 \mathrm{~b}$ \\
& Fallow & $0.0 \mathrm{c}$ & - & $0.0 \mathrm{c}$ \\
\hline Year & & $*$ & $*$ & $*$ \\
Treatment & $*$ & $*$ & $*$ \\
Year x Treatment & $*$ & $*$ & $\mathrm{NS}$
\end{tabular}

Within year, treatments followed by different letter are significantly different at $\mathrm{P}<0.05$ using the Duncan's test.

* Significant at the 0.05 probability level, or NS not significant in the ANOVA over treatments or years.

\subsection{Maize: Biomass, yield and N content}

Maize biomass and yield were not directly affected by treatment; however, maize biomass was affected by year (Table 2). The yield was affected by the interaction of the year and treatment. On average, maize yielded approximately $13.8 \mathrm{Mg} \mathrm{ha}^{-1}$ of grain, with 15.2 $\mathrm{Mg} \mathrm{ha}^{-1}$ of dry straw in 2013 and $11.2 \mathrm{Mg} \mathrm{ha}^{-1}$ in 2014. There was no difference in $\mathrm{N}$ content between 2013 and 2014; however, there were differences between treatments. On average, the maize after vetch had an uptake of $267 \mathrm{~kg} \mathrm{~N} \mathrm{ha}^{-1}$ in total aerial biomass, with approximately $200 \mathrm{~kg} \mathrm{~N} \mathrm{ha}^{-1}$ exclusively in the grain. Conversely, the maize after barley had an average uptake of only $192 \mathrm{~kg} \mathrm{~N} \mathrm{ha}^{-1}$, from which only $137 \mathrm{~kg} \mathrm{~N} \mathrm{ha}^{-1}$ was in the grain. The maize after the fallow treatment had an intermediate response, with $228 \mathrm{~kg} \mathrm{~N} \mathrm{ha}^{-1}$ average uptake and $157 \mathrm{~kg} \mathrm{~N} \mathrm{ha}^{-1}$ in the grain. There were no differences in the $\mathrm{N}$ harvest index between treatments; however, there were differences between years (approximately $0.68 \mathrm{~kg} \mathrm{~N}$ and $0.75 \mathrm{~kg} \mathrm{~N}$ grains per $\mathrm{kg} \mathrm{N}$ total aerial biomass during 2013 and 2014, respectively). Maize $\mathrm{N}$ concentrations revealed differences between treatments and years (Table 2) and were, approximately 10\% larger in 2013 than in 2014. The maize after vetch increased the $\mathrm{N}$ concentration in the grain with respect to the maize after barley by $2.6 \mathrm{~g} \mathrm{~N} \mathrm{~kg}^{-1}$, with the fallow treatment in between them. The $\mathrm{N}$ concentration in the remaining aerial biomass was $0.9 \mathrm{~g} \mathrm{~N} \mathrm{~kg}^{-1}$ lower for the maize after barley than after vetch. 
Table 2. Biomass and yield, carbon (CHI) and nitrogen (NHI) harvest index $\mathrm{N}$ concentration and $\mathrm{N}$ content for the grain and the rest of the aerial biomass of maize at harvest.

\begin{tabular}{|c|c|c|c|c|c|c|c|c|c|c|}
\hline \multirow[t]{2}{*}{$\begin{array}{l}\text { Growing } \\
\text { season }\end{array}$} & \multirow[t]{2}{*}{ Treatment } & \multicolumn{2}{|c|}{$\begin{array}{l}\text { Aerial Biomass } \\
\left(\mathrm{Mg} \text { d.m. } \text { ha }^{-1}\right)\end{array}$} & \multirow[t]{2}{*}{$\mathrm{CHI}$} & \multirow[t]{2}{*}{ NHI } & \multicolumn{2}{|c|}{$\begin{array}{l}\text { N Concentration } \\
\text { ( } \mathrm{g} \mathrm{N} \mathrm{kg}^{-1} \text { d.m.) }\end{array}$} & \multicolumn{3}{|c|}{$\begin{array}{l}\text { N Content } \\
\left(\mathrm{kg} \mathrm{N} \mathrm{ha}^{-1}\right)\end{array}$} \\
\hline & & Grain & Rest & & & Grain & Rest & Grain & Rest & Total \\
\hline \multirow[t]{3}{*}{2013} & Vetch & 15.13 & 15.87 & 0.49 & 0.69 & $13.3 \mathrm{a}$ & $5.5 \mathrm{a}$ & $202.6 \mathrm{a}$ & 87.6 & $290.2 \mathrm{a}$ \\
\hline & Barley & 12.45 & 13.42 & 0.48 & 0.69 & $11.1 \mathrm{~b}$ & $4.6 \mathrm{~b}$ & $135.3 \mathrm{~b}$ & 60.7 & $196.0 \mathrm{c}$ \\
\hline & Fallow & 13.64 & 16.29 & 0.46 & 0.65 & $12.4 \mathrm{ab}$ & $5.6 \mathrm{a}$ & $166.8 \mathrm{~b}$ & 90.2 & $257.0 \mathrm{~b}$ \\
\hline \multirow[t]{3}{*}{2014} & Vetch & 14.41 & 10.66 & 0.57 & 0.77 & $12.9 \mathrm{a}$ & $5.3 \mathrm{a}$ & $186.4 \mathrm{a}$ & 56.3 & $242.8 \mathrm{a}$ \\
\hline & Barley & 13.77 & 11.70 & 0.54 & 0.73 & $10.0 \mathrm{~b}$ & $4.3 \mathrm{~b}$ & $138.1 \mathrm{~b}$ & 50.4 & $188.4 \mathrm{c}$ \\
\hline & Fallow & 13.43 & 11.33 & 0.54 & 0.74 & $10.9 \mathrm{~b}$ & $4.5 \mathrm{~b}$ & $147.1 \mathrm{~b}$ & 51.7 & $198.8 \mathrm{~b}$ \\
\hline \multicolumn{2}{|l|}{ Year } & NS & $*$ & $*$ & $*$ & $*$ & $*$ & NS & $*$ & * \\
\hline \multicolumn{2}{|l|}{ Treatment } & NS & NS & NS & NS & $*$ & $*$ & $*$ & NS & $*$ \\
\hline \multicolumn{2}{|c|}{ Year x Treatment } & $*$ & NS & NS & NS & NS & NS & NS & NS & NS \\
\hline
\end{tabular}

Within year, treatments followed by different letter are significantly different at $\mathrm{P}<0.05$ using the Duncan's test.

* Significant at the 0.05 probability level, or NS not significant in the ANOVA over treatments or years.

\section{4. ${ }^{15} \mathrm{~N}$ recovered in the maize.}

The ${ }^{15} \mathrm{~N}$ concentration in the plant components was smaller in 2013 than in 2014 (Table 3). Differences between treatments in the ${ }^{15} \mathrm{~N}$ concentrations in the plant components were significant. The ${ }^{15} \mathrm{~N}$ concentration following the vetch treatment was on average $1.88 \%$ in the grain and $2.00 \%$ in the aerial biomass and was always smaller than that following the barley treatment $(2.33 \%$ and $2.42 \%$, respectively). The fallow treatment remained between the two, at $2.19 \%$ and $2.30 \%$, respectively, for the grain and the aerial biomass. The total $\mathrm{N}_{\mathrm{R}-\text { plant }}$ was different in 2013 and $2014\left(81.0 \mathrm{~kg} \mathrm{~N}^{-1}\right.$ and $91.8 \mathrm{~kg} \mathrm{~N} \mathrm{ha}^{-1}$, respectively, taken up directly from the fertiliser; Table 3). However, it was the same for all treatments over the 2 years $\left(86.1 \mathrm{~kg} \mathrm{~N} \mathrm{ha}^{-1}\right.$ on average, Table 3$)$. More $\mathrm{N}_{\mathrm{R} \text {-plant }}$ was observed in the grain both years $\left(51.9 \mathrm{~kg} \mathrm{~N} \mathrm{ha}^{-1}\right.$ and $68.8 \mathrm{~kg} \mathrm{~N} \mathrm{ha}^{-1}$, respectively) than in the rest of the aerial biomass $\left(28.5 \mathrm{~kg} \mathrm{~N} \mathrm{ha}^{-1}\right.$ and $23.0 \mathrm{~kg} \mathrm{~N} \mathrm{ha}^{-1}$, respectively); however, there were no differences between the treatments. The NUE was the same for all treatments, averaging $62.3 \%$ and $70.6 \%$ in 2013 and 2014 , respectively.

Differences between treatments appeared when the NOS was analysed. Maize following the vetch treatment had an uptake of $70 \mathrm{~kg}$ NOS ha ${ }^{-1}$ more on average than maize following the barley and $40 \mathrm{~kg}$ NOS $\mathrm{ha}^{-1}$ more than maize following the fallow 
treatment. Cover crop aerial biomass and $\mathrm{N}$ content were not related to NOS. Even in years with lower cover crop aerial biomass, the $\mathrm{N}$ effect on the maize was significant.

Table $3 .{ }^{15} \mathrm{~N}$ concentration and ${ }^{15} \mathrm{~N}$ content recovered in the grain and the rest of the aerial biomass of maize at harvest, $\mathrm{N}$ use efficiency (NUE), $\mathrm{N}$ from other sources (NOS) and apparent $\mathrm{N}$ mineralization (ANM) for three cover crop treatments during two consecutive years.

\begin{tabular}{|c|c|c|c|c|c|c|c|c|c|}
\hline \multirow{2}{*}{$\begin{array}{l}\text { Growing } \\
\text { season }\end{array}$} & \multirow[t]{2}{*}{ Treatment } & \multicolumn{2}{|c|}{${ }^{15} \mathrm{~N}$ Concentration (\%) } & \multicolumn{3}{|c|}{${ }^{15} \mathrm{~N}$ Recovered $\left(\mathrm{kg} \mathrm{N} \mathrm{ha}^{-1}\right)$} & \multirow{2}{*}{$\begin{array}{l}\text { NUE } \\
(\%)\end{array}$} & \multirow{2}{*}{$\begin{array}{l}\text { NOS } \\
\left(\mathrm{kg} \mathrm{N} \mathrm{ha}^{-1}\right)\end{array}$} & \multirow{2}{*}{$\begin{array}{l}\text { ANM } \\
\left(\mathrm{kg} \mathrm{N} \mathrm{ha}^{-1}\right)\end{array}$} \\
\hline & & Grain & Rest & Grain & Rest & Total & & & \\
\hline \multirow[t]{3}{*}{2013} & Vetch & $1.63 \mathrm{~b}$ & $1.91 \mathrm{~b}$ & 53.8 & 29.1 & 82.9 & 63.8 & $226.5 \mathrm{a}$ & $53.7 \mathrm{a}$ \\
\hline & Barley & $2.11 \mathrm{a}$ & $2.28 \mathrm{a}$ & 51.0 & 24.8 & 75.8 & 58.3 & $137.7 \mathrm{~b}$ & $48.3 \mathrm{a}$ \\
\hline & Fallow & $1.79 \mathrm{ab}$ & $2.10 \mathrm{ab}$ & 50.8 & 33.4 & 84.2 & 64.8 & $192.2 \mathrm{ab}$ & $26.3 \mathrm{~b}$ \\
\hline \multirow[t]{3}{*}{2014} & Vetch & $2.14 \mathrm{~b}$ & $2.10 \mathrm{c}$ & 71.6 & 21.1 & 92.7 & 71.3 & $171.5 \mathrm{a}$ & $92.3 \mathrm{a}$ \\
\hline & Barley & $2.54 \mathrm{a}$ & $2.57 \mathrm{a}$ & 64.7 & 24.0 & 88.6 & 68.2 & $120.3 \mathrm{~b}$ & $39.7 \mathrm{~b}$ \\
\hline & Fallow & $2.58 \mathrm{a}$ & $2.49 \mathrm{~b}$ & 70.1 & 23.8 & 94.0 & 72.3 & $126.5 \mathrm{~b}$ & $36.3 \mathrm{~b}$ \\
\hline \multicolumn{2}{|l|}{ Year } & $*$ & $*$ & $*$ & $*$ & $*$ & $*$ & $*$ & $\mathrm{NS}$ \\
\hline \multicolumn{2}{|l|}{ Treatment } & $*$ & $*$ & NS & NS & NS & NS & $*$ & $*$ \\
\hline \multicolumn{2}{|c|}{ Year $\mathrm{x}$ Treatment } & NS & NS & NS & NS & NS & NS & NS & $*$ \\
\hline
\end{tabular}

Within year, treatments followed by different letter are significantly different at $\mathrm{P}<0.05$ using the Duncan's test.

* Significant at the 0.05 probability level, or NS not significant in the ANOVA over treatments or years.

\subsection{Residual $N$ in the soil and total recovery}

The amount of $\mathrm{N}_{\mathrm{R} \text {-soil }}$ after maize harvest did not differ between years or treatments (Fig. 3). In all treatments, the amount of $\mathrm{N}_{\mathrm{R} \text {-soil }}(1 \mathrm{~m})$ was approximately $42 \mathrm{~kg} \mathrm{~N}^{-1}$ (equivalent to $32 \%$ of the fertiliser applied). Analysing layer by layer, there were no differences except in the shallowest $0.20 \mathrm{~m}$. At this depth, the $\mathrm{N}_{\mathrm{R} \text {-soil }}$ in the barley treatment was larger than that in the fallow treatment, with the vetch treatment in between them. This effect was observed in 2014 but not in 2013 .

Most of the $\mathrm{N}_{\mathrm{R} \text {-soil }}$ after the maize harvest was found in the upper 0.40-m layer (ranging from $65.9 \%$ to $84.6 \%$ of the total amount recovered from the soil for all treatments and years). Only a small fraction was found below $0.80 \mathrm{~m}$ (between $3.5 \%$ and $11.7 \%$ of the total $\mathrm{N}_{\mathrm{R} \text {-soil }}$ for all treatments and years) (Fig. 3). Combining $\mathrm{N}_{\mathrm{R} \text {-soil }}$ and $\mathrm{N}_{\mathrm{R} \text {-soil }}$, the estimated direct losses from the fertiliser were on the order of $5 \mathrm{~kg} \mathrm{~N} \mathrm{ha}^{-1}$ without the differences between the treatments or years (Fig. 4). 


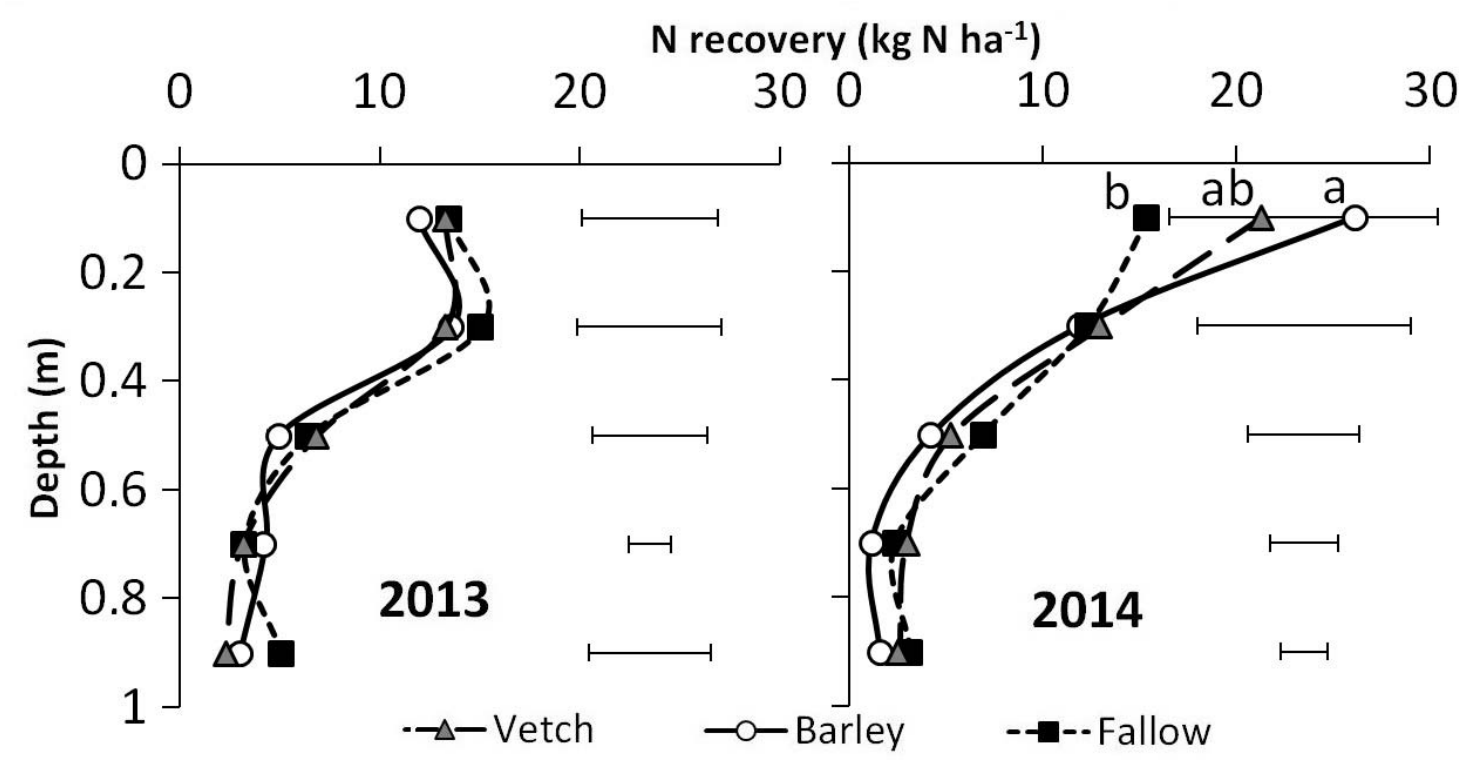

Figure 3. $\mathrm{N}$ recovered from fertiliser profiles after a maize crop. Fertilizer application was $130 \mathrm{~kg} \mathrm{~N} \mathrm{ha}^{-1}$, labelled with ${ }^{15} \mathrm{~N}$. Within year and depth, treatments followed by different letters are significantly different at $\mathrm{P}<0.05$ using Duncan's test.

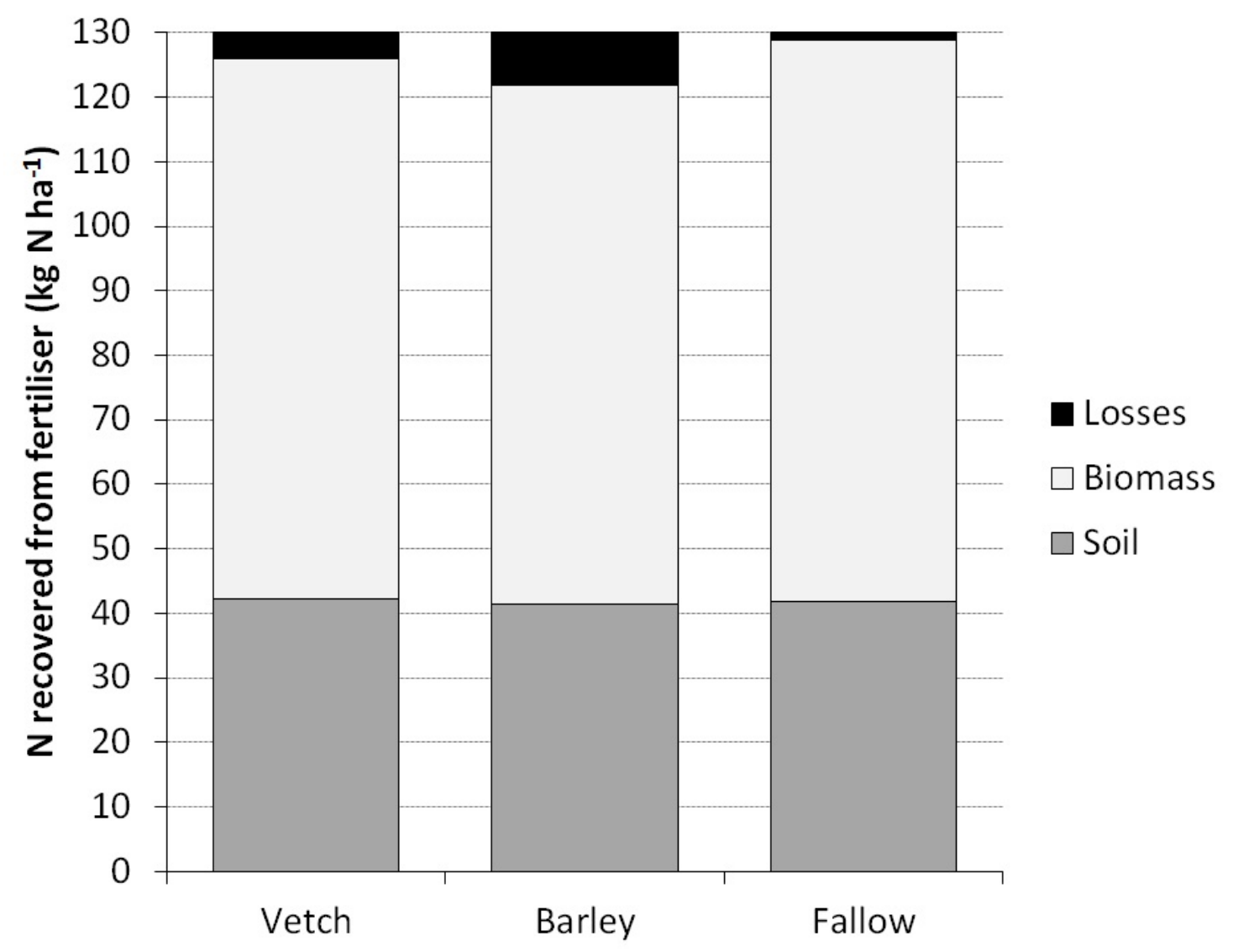

Figure 4. Average ${ }^{15} \mathrm{~N}$ recovered in the biomass, in the soil and lost during the two maize cropping seasons. The total $\mathrm{N}$ applied with the labelled fertiliser was $130 \mathrm{~kg} \mathrm{~N} \mathrm{ha}^{-1}$. No differences were observed between treatments at $\mathrm{P}<0.05$ using Duncan's test. 
The $\mathrm{N}_{\min }$ profiles were different for the various sampling times, years and treatments (Fig. 5). In general, profiles in 2013 accumulated more $\mathrm{N}_{\min }$ than profiles in 2014 for the three treatments before maize sowing and after harvest. The use of barley as a cover crop reduced $\mathrm{N}_{\min }$ at maize sowing at all depths with respect to the fallow treatment and, most of the time, with respect to the vetch treatment. However, these differences disappeared after cropping the maize, when all treatments presented similar profiles, even though vetch increased its $\mathrm{N}_{\min }$ content at $0.80-1.0 \mathrm{~m}$ depth. This effect was the same both years, and only at the $0-0.20 \mathrm{~m}$ depth layer was the $\mathrm{N}_{\min }$ larger during 2013 than in 2014.

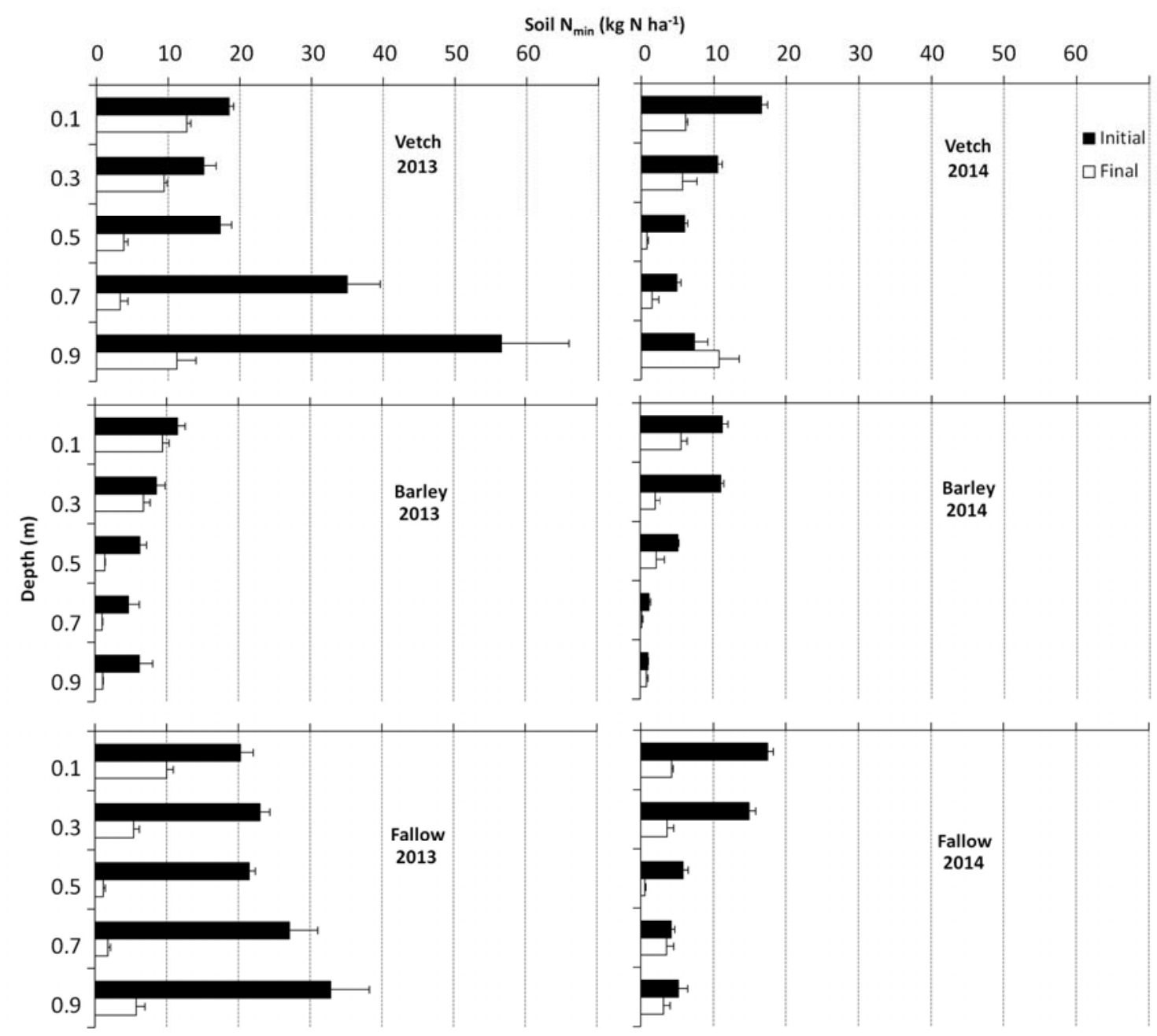

Figure 5. Soil mineral $\mathrm{N}$ content profiles (non-labelled) before and after a maize crop affected by the three cover crop treatments before maize sowing and during two consecutive years. Horizontal bars represent the standard error. 
A simple $\mathrm{N}$ balance was conducted, and there was no difference between years in ANM, even though there was an interaction between the treatment and years (Table 3). The vetch treatment increased ANM by approximately $42 \mathrm{~kg} \mathrm{~N} \mathrm{ha}^{-1}$ with respect to the fallow treatment both years, with the barley treatment in between (not different from the vetch in 2013 but lower in 2014). It is interesting to note that in 2014, the difference between ANM from the vetch treatment and from the fallow treatment $\left(56 \mathrm{~kg} \mathrm{~N} \mathrm{ha}^{-1}\right)$ was larger than the $\mathrm{N}$ content of the cover crop residue.

\section{DISCUSSION}

\subsection{Cover crops: Biomass, $N$ content and $N$ uptake}

The cover crop biomass production was affected by the weather conditions and the $\mathrm{N}$ availability. Cover crops usually grow during periods of the year when conditions are not optimal for growing cash crops; therefore, biomass accumulation and $\mathrm{N}$ uptake are expected to vary depending on the yearly meteorological conditions (Lal et al., 1991; Thorup-Kristensen et al., 2003). During the second season, conditions were less suitable for cover crop growth in autumn (lower temperature and precipitation) and at the end of winter (lower rainfall), when the cover crops can produce large amounts of biomass in a favourable year. This resulted in larger biomass production and faster ground cover during the first season with respect to the second. Unger and Vigil (1998) previously noted that the main constraints for cover cropping in semiarid regions were the water availability at sowing and the reliable precipitation and cold temperatures during the growing season. Between treatments, barley showed a better adaptation to cold and dry conditions than vetch, covering the ground faster before the winter. These results are in agreement with Bilbro (1991), Unger and Vigil (1998) and Ramírez-García et al (2015).

However there were differences with respect to these studies because in this study, there was also another relevant factor, the soil $\mathrm{N}$ availability. In the barley treatment, soil available $\mathrm{N}$ at cover crop sowing was lower than in the vetch treatment, reducing the biomass production in the grass with respect to the legume in 2012/13 and the $\mathrm{N}$ content at cover crop killing date in both seasons. This is in agreement with the studies of Tosti et al. (2012), who observed larger production of biomass for legume than grass cover crops under low soil $\mathrm{N}$ availability conditions. In the study of Gabriel and Quemada (2011) in the same plots, the soil $\mathrm{N}$ availability at cover crop sowing was never a 
limiting factor for cover crops, and therefore, the barley produced more biomass than the legume. The low $\mathrm{N}$ availability caused, for the first time in this long-term experiment, a reduction in the barley biomass with respect to the vetch and in the $\mathrm{N}$ concentration in the barley with respect to that observed by Gabriel and Quemada (2011) in the $2007-2009$ period (1.62\% versus $2.14 \%$, respectively). However, there were no differences in the $\mathrm{N}$ biomass content and the $\mathrm{N}$ concentration in the vetch with respect to those previously observed $(\sim 3.75 \%)$ by Gabriel and Quemada (2011), primarily due to atmospheric $\mathrm{N}_{2}$ fixation. Under these conditions, barley had an uptake of $11 \mathrm{~kg} \mathrm{~N} \mathrm{ha}^{-1}$ during the second season, far from the $157 \mathrm{~kg} \mathrm{~N} \mathrm{ha}^{-1}$ observed in 2006/07. A broad range of $\mathrm{N}$ uptakes has been observed in the literature, ranging from $10 \mathrm{~kg} \mathrm{~N} \mathrm{ha}^{-1}$ (Richards et al., 1996; Ranells and Wagger, 1997) to $200 \mathrm{~kg} \mathrm{~N} \mathrm{ha}^{-1}$ (Müller and Sundman, 1988; Thorup-Kristensen, 1994; Jackson et al., 1993). This flexibility makes barley a good $\mathrm{NO}_{3}{ }^{-}$catch crop because its growth is adapted to the soil $\mathrm{N}$ availability. Nevertheless, if the goal is to reach ground cover $>70 \%$ to control soil erosion (Quinton et al. 1997), vetch seems to be a better fit when low residual $\mathrm{N}$ is left after the main crop. Cereal-legume mixtures are likely a good solution, combining the quick initial growth of the grass with the ground cover provided by vetch in winter (Alonso-Ayuso et al. 2014).

\subsection{Maize: Biomass, yield and $N$}

Replacing the fallow treatment with cover crops did not diminish the yield or biomass of the maize. Tonitto et al. (2006) reported in a meta-analysis that introducing a cover crop did not produce yield differences with respect to the fallow treatment, when $\mathrm{N}$ fertiliser was adapted to the requirements of the main crop. However, when the $\mathrm{N}$ application is reduced, the results are more uncertain. Usually, under suboptimal $\mathrm{N}$ fertilisation, a non-response or an increase in yield is reported after legumes (Tonitto et al. 2006) and a non-response or a decrease after grasses (Thorup-Kristensen, 1994; Vyn et al., 1999; Quemada et al., 2013). The results of $\mathrm{N}$ uptake after cover crops in the literature vary greatly (Thorup-Kristensen et al., 2003). Maize N uptake after cover crops when the $\mathrm{N}$ fertiliser satisfies the crop's demand usually do not present differences between cover crop or fallow treatments (Miguez and Bollero, 2005). In our experiment, the $\mathrm{N}$ uptake by maize increased if there was a vetch instead of a fallow treatment (38 $\mathrm{kg} \mathrm{N} \mathrm{ha}^{-1}$ on average) and decreased if it was a barley treatment (36 kg N 
$\mathrm{ha}^{-1}$ ). The differences were noticeable in the grain $\mathrm{N}$, but not in the $\mathrm{N}$ remaining in the rest of the aerial biomass.

After 7 years of reduced tillage in the field experiment the yield and biomass were similar to those obtained in the initial year (Gabriel and Quemada, 2011), even if the fertiliser application was reduced from $210 \mathrm{~kg} \mathrm{~N} \mathrm{ha}^{-1}$ to $130 \mathrm{~kg} \mathrm{~N} \mathrm{ha}^{-1}$. This result suggests that the previous used $\mathrm{N}$ rate of $210 \mathrm{~kg} \mathrm{~N}^{-1}$ was higher than the recommended rate, previously reported as $170 \mathrm{~kg} \mathrm{~N}^{-1}$ for maize in this region (Quemada et al. 2014). Under the suboptimal fertilisation in this experiment, the extra $\mathrm{N}$ supply ( $\left.\sim 40 \mathrm{~kg} \mathrm{~N} \mathrm{ha}^{-1}\right)$ in the vetch treatment did not translate into a yield increase but rather to an increase in the grain $\mathrm{N}$ content.

The ${ }^{15} \mathrm{~N}$ analysis showed that the high NUE was obtained by keeping the soil available $\mathrm{N}$ low and reducing the $\mathrm{N}$ fertilisation with respect to the previous recommendations. There were no differences between treatments; however, there were differences between years $(62.3 \%$ and $70.6 \%$ on average during 2013 and 2014, respectively). The NUE is in the high range reported in the literature, compared to values of $43-57 \%$ observed by Reddy and Reddy (1993), 39-64\% observed by Bundy and Andraski (2005) or even the 64-66\% reported by Normand et al. (1997). Therefore, we confirmed that when reducing the fertiliser application below the crop requirements, the effect of cover crops on NUE was not significant. This is relevant because Quemada and Gabriel (2011) suggested that the low NUE (40-51\%) after the application of $210 \mathrm{~kg} \mathrm{~N} \mathrm{ha}^{-1}$ could mask the effect of cover crops on NUE. However, it has been proven that even if the legume was incorporating $\mathrm{N}$ into the system by atmospheric $\mathrm{N}_{2}$ fixation, the amount of $\mathrm{N}$ derived from the fertiliser that was taken up by the maize was similar to that in the other treatments.

The differences between treatments in maize $\mathrm{N}$ uptake resulted from a $\mathrm{N}$ supply by sources other than the fertiliser (NOS). Maize after vetch recovered on average $40 \mathrm{~kg} \mathrm{~N}$ $\mathrm{ha}^{-1}$ more than the fallow treatment from other sources and $70 \mathrm{~kg} \mathrm{~N} \mathrm{ha}^{-1}$ more than the barley treatment. In 2014, this increase in NOS uptake by the maize after the vetch was larger than the $\mathrm{N}$ content on the aerial biomass of the vetch, suggesting that continuous cover cropping rotation with legumes enhanced the soil $\mathrm{N}$ mineralization supply. Other authors have also observed the effect of legumes as a fertiliser equivalent; however, the results are extremely variable. Decker at al. (1994) found that $\mathrm{N}$ uptake by maize 
increased 50-70 $\mathrm{kg} \mathrm{N} \mathrm{ha}^{-1}$ after legume cover cropping, and Stute and Posner (1995) found an increase of $72-115 \mathrm{~kg} \mathrm{~N} \mathrm{ha}^{-1}$ after vetch. Andraski and Bundy (2005) observed that after 2-3 years, fertilisation could be reduced by $32 \mathrm{~kg} \mathrm{~N} \mathrm{ha}^{-1}$ for an economic optimum when cover crops were introduced. Again, this variability reinforces the importance of factors other than direct supply by the preceding cover crop aerial biomass. In our study, the cover crop aerial biomass was not a good indicator of the $\mathrm{N}$ supply to the subsequent crop. Furthermore, the difference in ANM between the vetch and the fallow treatment was larger than the cover crop $\mathrm{N}$ content. Therefore, in addition to the year-long effect of residue decomposition, there was a cumulative effect on the soil $\mathrm{N}$ mineralization supply of the cover crop treatments, which was more evident for the vetch treatment than for the fallow treatment. This result agrees with Raimbault et al. (1990), Kuo and Jellum (2002) or Kramberger et al. (2014), supporting the idea that the cover crop aboveground can be removed without causing a yield decrease in the subsequent cash crop, even though it may have an effect on the long term yields. This suggests that making an allowance for the $\mathrm{N}$ supply from the cover crop is better achieved by using $\mathrm{N}$ nutritional indexes (i.e., optical crop sensors) to adjust the $\mathrm{N}$ fertiliser application to the subsequent cash crop than by estimating the $\mathrm{N}$ content in the biomass of the previous cover crop.

Finally, the N harvest index, 0.68 in 2013 and 0.75 in 2014, was in the same range as those observed in the 2007/2009 period without differences between treatments (on average, from $0.66 \%$ to $0.80 \%$, Gabriel and Quemada, 2011). Similar values were reported by Bundy and Andraski (2005; between 42\% and 81\%) and by Chen et al. (2015; between $66 \%$ and $73 \%$ ), who compared different maize hybrids at different $\mathrm{N}$

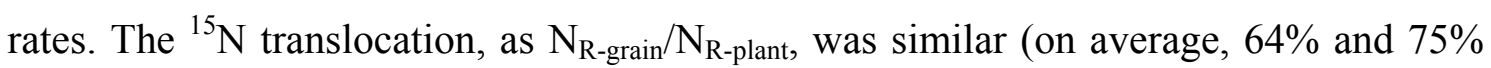
for each year; Table 3) showing not preferential discrimination for any of the stable $\mathrm{N}$ isotopes.

\subsection{Residual $N$ in the soil and total recovery}

There were no differences in the amount of $\mathrm{N}_{\mathrm{R} \text {-soil }}$ in the $1 \mathrm{~m}$-depth soil profile between treatments. Only in the $0-0.20 \mathrm{~m}$ layer did the $\mathrm{N}_{\mathrm{R} \text {-soil }}$ in the barley treatment increase, likely due to the immobilization caused by the low $\mathrm{N}$ concentration of the barley residue and the low soil $\mathrm{N}$ availability. The distribution of ${ }^{15} \mathrm{~N}$ profiles followed the pattern described by other authors, with the majority of the $\mathrm{N}_{\mathrm{R} \text {-soil }}$ in the upper $0.40 \mathrm{~m}$ and small 
amounts below 0.80 m (Jenkinson et al., 1985; Hart et al., 1986; Rao et al. 1991; Reddy and Reddy, 1993; Ottman et al., 2000; Gabriel and Quemada, 2011). This strong retention in the upper layer is explained primarily by pool substitution between ${ }^{14} \mathrm{~N}$ and ${ }^{15} \mathrm{~N}$ in the microbial biomass and the stable organic matter fraction (Jenkinson et al., 1985; Hart et al., 1986; Rao et al. 1991; Timmons and Cruse, 1991) and to a lesser extent in the maize root system (Gabriel and Quemada, 2011). When compared to the results of 2007/2009 in the same experiment field, the ${ }^{15} \mathrm{~N}$ substitution seems to be favoured by larger fertiliser application or lower fertiliser use efficiency. Gabriel and Quemada (2011) observed that the ${ }^{15} \mathrm{~N}$ retained in the soil was between $27 \%$ and $52 \%$ of the total $\left(210 \mathrm{~kg} \mathrm{~N} \mathrm{ha}^{-1}\right)$ applied, whereas in the present study, with an application of

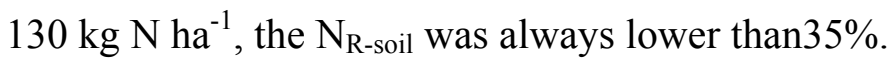

Another consequence of the results is that ${ }^{15} \mathrm{~N}$-labelled fertiliser methods are not appropriate for leaching loss measurements. The isotopic discrimination of ${ }^{15} \mathrm{~N}$ by soil microorganisms and its retention in the upper layer led to an underestimate in the nitrate leaching (Ottman et al. 2000). Most of the ${ }^{15} \mathrm{~N}$ was recovered in the top $0.40 \mathrm{~m}$ layer, and very little reached the bottom $0.80-1.0 \mathrm{~m}$ layer. However, the non-labelled mineral $\mathrm{N}$ profiles showed a downward movement of $\mathrm{N}$ in the soil, which is explained by the leaching fraction $(\sim 10 \%)$ used in irrigation scheduling. The total ${ }^{15} \mathrm{~N}$ recovered in the soil-plant systems was very high (non-significantly different from 100\% in any treatment), suggesting very low $\mathrm{N}$ losses from the system. Ottman et al. (2000) also concluded, via a comparison of ${ }^{15} \mathrm{~N}$ and bromide as fertiliser tracers in irrigated wheat fields, that the ${ }^{15} \mathrm{~N}$ technique was not a good method to estimate $\mathrm{N}$ fertiliser movement.

\section{CONCLUSIONS}

Reducing the $\mathrm{N}$ fertilisation to maize (from $210 \mathrm{~kg} \mathrm{~N} \mathrm{ha}^{-1}$ to $130 \mathrm{~kg} \mathrm{~N} \mathrm{ha}^{-1}$ ) led to low soil available $\mathrm{N}$ throughout the experiment, enhancing the $\mathrm{N}$ fertiliser use efficiency and controlling losses out of the system. Both goals were achieved, as was the risk of increasing pre-emptive competition with the subsequent cash crop, observed via the lower maize $\mathrm{N}$ uptake after the barley and fallow treatments.

Replacing the fallow treatment with cover crops in a maize production system with suboptimal $\mathrm{N}$ fertilisation affected the $\mathrm{N}$ uptake but did not have an effect on the 
biomass or $\mathrm{C} / \mathrm{N}$ translocation to grain, and the subsequent yield was only affected by the interaction between the year and treatment. Replacing the fallow treatment with vetch increased $\mathrm{N}$ uptake, whereas replacing it with barley reduced uptake, primarily via the grain $\mathrm{N}$ content.

The low $\mathrm{N}$ fertiliser supply allowed a high NUE, averaging $66.5 \%$. The effect of cover crops on NUE was not significant, proving that even if the legume was incorporating $\mathrm{N}$ into the system by atmospheric $\mathrm{N}_{2}$ fixation, the amount of $\mathrm{N}$ derived from the fertiliser that was taken up by the maize was not reduced when compared to the fallow treatment or the grass cover crop.

Soil ${ }^{15} \mathrm{~N}$ recovery was the same for all treatments and depths, except for an increase in the $0-0.20-\mathrm{m}$ layer in the cover crop treatments during 2014 . Fertiliser ${ }^{15} \mathrm{~N}$ was primarily retained in the upper layers, suggesting that ${ }^{15} \mathrm{~N}$ was substituting ${ }^{14} \mathrm{~N}$ in the fairly stable organic fraction. Even though, all treatments presented low $\mathrm{N}_{\text {min }}$ profiles after maize growth, barley also reduced the $\mathrm{N}_{\min }$ content prior to maize planting, increasing the risk of pre-emptive competition with the subsequent maize crop. The vetch and fallow treatments were able to maintain higher soil available $\mathrm{N}$ in the top layers at planting.

Under low soil available $\mathrm{N}$ conditions, barley was faster to cover the ground than vetch before winter. However, the legume presented a larger ground cover and $\mathrm{N}$ content by the time it was killed. Barley was a good $\mathrm{N}$ scavenger, reducing the risk of $\mathrm{NO}_{3}{ }^{-}$ leaching; however, care should be taken concerning a possible pre-emptive competition with the subsequent maize crop. The vetch treatment increased $\mathrm{N}$ supply with respect to the barley and fallow treatments but also increased the $\mathrm{NO}_{3}{ }^{-}$leaching risk with respect to barley. The enhancement of soil apparent $\mathrm{N}$ mineralization by the cover crops indicated that, in addition to the year-long effect of residue decomposition, there was a cumulative effect in the capacity of the soil to supply $\mathrm{N}$ after 7 years of cover cropping, which was more evident for vetch than for barley.

\section{ACKNOWLEDGEMENTS}

Spanish Ministry of Economy and Competitiveness (AGL201452310R; IJCI201420175), and Comunidad de Madrid (S2013/ABI2717). 


\section{REFERENCES}

Allen, R.G., Pereira, L.S., Raes D., Smith, M., 1998. FAO 56 Irrigation and drainage paper: crop evapotranspiration. Food and agriculture Organization. Rome.

Alonso-Ayuso, M., Gabriel, J.L., Quemada, M., 2014. The kill date as management tool for cover cropping success. PlosOne 9, e109587.

Andraski, T.W., Bundy, L.G., 2005. Cover crop effects on corn yield response to nitrogen on an irrigated sandy soil. Agron. J. 97, 1239-1244.

Bilbro, JD., 1991. Cover crops for wind erosion control in semiarid regions. In W.L. Hargrove (ed.) Cover crops for clean water. Soil Water Conserv. Soc., Ankeny, IA, US. pp. 36-38.

Bundy, L.G., Andraski, T.W., 2005. Recovery of fertilizer nitrogen in crop residues and cover crops on an irrigated sandy soil. Soil Sci. Soc. Am. J. 69, 640-648.

Campiglia, E., Caporali, F., Radicetti, E., Mancinelli, R., 2010. Hairy vetch (Vicia villosa Roth.) cover crop residue management for improving weed control and yield in no-tillage tomato (Lycopersicon esculentum Mill.) production. Europ. J. Agron. 33, 94102.

Chen, Y., Xiao, C., Wu, D., Xia, T., Chen, Q., Chen, F., Yuan, L., Mi, G., 2015. Effects of nitrogen application rate on grain yield and grain nitrogenconcentration in two maize hybrids with contrasting nitrogenremobilization efficiency. Euro. J. Agron. 62, 79-89.

Decker, A.M., Clark, A.J., Meisinger, J.J., Mulford, F.R., McIntosh, M.S., 1994. Legume cover crop contributions to no-tillage corn production. Agron. J. 86, 126-135.

Doane, T.A., Horwath, W.R., Mitchell, J.P., Jackson, J., Miyao, G., Brittan, K., 2009. Nitrogen supply from fertilizer and legume cover crop in the transition to no-tillage for irrigated row crops. Nutr. Cycl. Agroecosyst. 85, 253-262.

Gabriel, J.L., Quemada, M., 2011. Replacing bare fallow with cover crops in a maize cropping system: Yield, N uptake and fertiliser fate. Eur. J. Agron., 34, 133-143. 
Gabriel, J.L., Almendros, P., Hontoria, C., Quemada, M., 2012a. The role of cover crops in irrigated systems: Soil salinity and salt leaching. Agric. Ecosyst. Environ., 158, 200-207.

Gabriel, J.L., Muñoz-Carpena, R., Quemada, M., 2012b. The role of cover crops in irrigated systems: water balance, nitrate leaching and soil mineral nitrogen accumulation. Agric. Ecosyst. Environ., 155, 50-61.

Gabriel, J.L., Garrido, A., Quemada, M., 2013. Cover crops effect on farm benefits and nitrate leaching: Linking economic and environmental analysis. Agr. Syst., 121, 23-32.

Gabriel, J.L., Vanclooster, M., Quemada, M., 2014. Integrating wáter, nitrogen, and salinity in sustainable irrigated systems: cover crops versus fallow. J. Irrig. Drain Eng. 140, A4014002.

Garibay, S.V., Stamp, P., Ammon, H.U., Feil, B., 1997. Yield and quality components of silage maize in killed and live cover crop sods. Europ. J. Agron. 6, 179-190.

Haas, G., Brand, H., de la Vega, M.P., 2007. Nitrogen from hairy vetch (Vicia villosa roth) as winter green manure for white cabbage in organic horticulture. Bio. Agric. Hort. 25, 37-53.

Hanly, J.A., Gregg, P.E.H., 2004. Green-manure impacts on nitrogen availability to organic sweetcorn (Zea mays). New Zealand J. Crop Hort. Sci. 32, 295-307.

Hargrove, W.L., 1991. Cover crops for clean water. Soil and water conservation Soc, Ankeny, IA, USA.

Hart, P.B.S., Rayner, J.H., Jenkinson, D.S., 1986. Influence of pool substitution on the interpretation fertilizer experiments with N-15. Journal of Soil Science 37, 389-403.

Hauck, R.D., Bremner, J.M., 1976. Use of tracers for soil and fertilizer nitrogen research. Adv. Agron. 28, 219-266.

Hutcheson, G.D., 2013. Data analysis using R commander: An introduction to using R commander. SAGE Publications Ltd, London, UK.

Jackson, L.E., Wyland, L.J., Stivers, L.J., 1993. Winter cover crops to minimize nitrate losses in intensive lettuce production. J. Agric. Sci. 121, 55-62. 
Jenkinson, D.S., Fox, R.H., Rayner, J.H., 1985. Interactions between fertilizer nitrogen and soil-nitrogen - the so-called priming effect. Journal of Soil Science 36, 425-444.

Keenney, D.R., Nelson, D.W., 1982. Nitrogen-inorganic forms. In: Page, A.L. (ed.), Methods of soil analysis. Part 2: Chemical and microbiological properties. ASA and SSSA, Madison, WI, US. pp. 643-698.

Kramberger, B., Gselman, A., Janzekovic, M., Kaligaric, M., Bracko, B., 2009. Effects of cover crops on soil mineral nitrogen and on yield and nitrogen content of maize. Europ. J. Agronomy 31, 103-109.

Kramberger, B., Gselman, A., Kristl, J., Lesnik, M., Sustar, V., Mursec, M. Podvrsnik, M., 2014. Winter cover crop: the effects of grass-clover mixture proportion andbiomass management on maize and the apparent residual $\mathrm{N}$ in the soil. Europ. J. Agron. 55, 6371.

Kuo, S., Sainju, U.M., Jellum, E.J., 1997. Winter cover crop effects on soil organic carbon and carbohydrate in soil. Soil Sci. Soc. Am. J. 61, 145-152.

Kuo, S., Jellum, E.J., 2002. Influence of winter cover crop and residue management on soil nitrogen availability and corn. Agron. J. 94, 501-508.

Lal, R., Regnier, E., Eckert, D.J., Edwards, W.M., Hammond, R., 1991. Expectations of cover crops for sustainable agriculture. In: Hargrove, W.L. (ed.) Cover crops for clean water. Soil Water Conserv. Soc., Ankeny, IA, US. pp. 1-10.

Martínez-Cob, A., 2008. Use of thermal units to estimate corn crop coefficients under semiarid climatic conditions. Irrig. Sci. 26, 335-345.

McCracken, D.V., Smith, M.S., Grove, J.H., Mackown, C.T., Blevins, R.L., 1994. Nitrate leaching as influenced by cover cropping and nitrogen-source. Soil Sci. Soc. Am. J., 58, 1476-1483.

Miguez, F.E., Bollero, G.A., 2005. Review of corn yield response under winter cover cropping systems using meta-analytic methods. Crop Sci. 45, 2318-2329.

Müller, M.M., Sundman, V., 1988. The fate of nitrogen $(15 \mathrm{~N})$ released from different plant materials during decomposition under field conditions. Plant Soil 105, 133-139. 
Normand, B., Recous, S., Vachaud, G., Kengni, L., Garino, B., 1997. Nitrogen-15 tracers combined with tension-neutronic method to estimate the nitrogen balance of irrigated maize. Soil Sci. Soc. Am. J. 61, 1508-1518.

Ottman, M.J., Tickes, B.R., Husman, S.H., 2000. Nitrogen-15 and bromide tracers of nitrogen fertilizer movement in irrigated wheat production. J. Environ. Qual. 29, 15001508.

Papadakis, J., 1966. Climates of the world and their agricultural potentialities. DAPCO, Rome, Italy.

Quemada, M., Cabrera, M.L., 2002. Characteristic moisture curves and maximum water content of two crop residues. Plant Soil 238, 295-299.

Quemada, M., Baranski, M., Nobel-de Lange, M.N.J., Vallejo, A., Cooper, J.M., 2013. Meta-analysis of strategies to control nitrate leaching in irrigated agricultural systems and their effects on crop yield. Agric. Ecosyst. Environ. 174, 1-10.

Quemada, M., Gabriel, J.L., Zarco-Tejada, P., 2014. Airborne hyperspectral images and ground-level optical sensors as assessment tools for maize nitrogen fertilization. Remote Sensing 6, 2940-2962.

Quinton, J.N., Edwards, G.M., Morgan, R.P.C., 1997. The influence of vegetation species and plant properties on runoff and soil erosion: results from a rainfall simulation study in south east Spain. Soil Use and Management 13, 143-148.

Raimbault, B.A., Vyn, T.J., Tollenaar, M., 1990. Corn response to rye cover crop management and spring tillage systems. Agron. J., 82, 1088-1093.

Ramirez-García, J., Gabriel, J., Alonso-Ayuso, M., Quemada, M., 2015. Quantitative characterization of five cover crop species. J. Agric. Sci. 153, 1174-1185.

Ranells, N.N., Wagger, M.G., 1997. Winter annual grass-legume bicultures for efficient nitrogen management in no-till corn. Agric. Ecosyst. Environ. 65, 23-32.

Rao, A.C.S., Smith, J.L., Papendick, R.I., 1991. Influence of added nitrogen interactions in estimating recovery efficiency of labeled nitrogen. Soil Sci. Soc. Am. J. 55, 16161621. 
Reddy, G.B., Reddy, K.R., 1993. Fate of nitrogen-15 enriched ammonium nitrate applied to corn. Soil Sci. Soc. Am. J. 57, 111-115.

Richards, I.R., Wallace, P.A., Turner, I.D.S., 1996. A comparison of six cover crop types in terms of nitrogen uptake and effect on response to nitrogen by a subsequent spring barley crop. J. Agric. Sci. 127, 441-449.

Roberson, E.B., Saring, S., Firestone, M.K., 1991.Cover crop management of polysaccharide-mediated aggregation in an orchard soil. Soil Sci. Soc. Am. J. 55, 734739.

Ruegg, W.T., Richner, W., Stamp, P., Feil, B., 1998. Accumulation of dry matter and nitrogen by minimum-tillage silage maize planted into winter cover crop residues. Europ. J. Agron. 8, 59-69.

Salmerón, M., Cavero, J., Quílez, D., Isla, R., 2010. Winter cover crops affect monoculture maize yield and nitrogen leaching under irrigated Mediterranean conditions. Agron. J., 102, 33-42.

Soil Survey Staff, 2014. Keys to Soil Taxonomy. USDA, Natural Resources Conservation Service. Madison, WI, USA.

Solorzano, L., 1969. Determination of ammonia in natural waters by the phenolhypoclorite method. Limnol. Oceanogr. 14, 799-801.

Stute, J.K., Posner, J.L., 1995. Legume cover crops as a nitrogen source for corn in an oat-corn rotation. J. Prod. Agric. 8, 385-390.

Thorup-Kristensen, K., 1994. The effect of nitrogen catch crop species on the nitrogen nutrition of the succeeding crops. Fert. Res. 37, 227-234.

Thorup-Kristensen, K., 2001. Are differences in root growth of nitrogen catch crops important for their ability to reduce soil nitrate-N content, and how can this be measured? Plant Soil 230, 185-195.

Thorup-Kristensen, K., Magid, J., Jensen, L.S., 2003. Catch crops and green manures as biological tools in nitrogen management in temperate zones. Adv. Agron.79, 227-302. 
Timmons, D.R., Cruse, R.M., 1991. Residual N-15 recovery by corn as influenced by tillage and fertilization method. Agron. J. 83, 357-363.

Tonitto, C., David, M.B., Drinkwater, L.E., 2006. Replacing bare fallows with cover crops in fertilizer-intensive cropping systems: A meta-analysis of rop yield and $\mathrm{N}$ dynamics. Agric. Ecosyst. Environ. 112, 58-72.

Tosti, G., Benincasa, P., Farneselli, M., Pace, R., Tei, F., 2012. Green manuring effect of pure and mixed barley-hairy vetch winter cover crops on maize and processing tomato N nutrition. Europ. J. Agronomy 43: 136-146.

Unger, P.W., Vigil, M.F., 1998. Cover crops effects on soil water relationships. J.Soil Water Conserv. 53, 200-2007.

Verhulst, N., Nelissen, V., Jespers, N., Haven, H., Sayre, K.D., Raes, D., Deckers, J., Govaerts, B., 2011. Soil water content, maize yield and its stability as affected by tillage and crop residue management in rainfed semi-arid highlands. Plant Soil 344, 73-85.

Vyn, T.J., Janovicek, K.J., Miller, M.H., Beauchamp, E.G., 1999. Soil nitrate accumulation and corn response to preceding small-grain fertilization and cover crops. Agron. J. 91, 17-24.

Wagger, M.G., Mengel, D.B., 1988. The role of nonleguminous cover crops in the efficient use of water and nitrogen. In: Hargrove, W.L. (ed.), Cropping strategies for efficient use of water and nitrogen. ASA Spec. Publ. no. 51, Madison, WI, USA. pp $115-127$. 